\title{
Sox9 mediates Notch1-induced mesenchymal features in lung adenocarcinoma
}

\author{
Kathleen M. Capaccione ${ }^{1,2}$, Xuehui Hong2,3, Katherine M. Morgan ${ }^{1,2}$, Wenyu Liu ${ }^{2}$, \\ Michael J. Bishop ${ }^{4}$, LianXin Liu ${ }^{3}$, Elke Markert' ${ }^{2,5}$, Malik Deen ${ }^{6}$, Christine Minerowicz ${ }^{6}$, \\ Thaddeus Allen ${ }^{4}$ and Sharon R. Pine ${ }^{1,2,5}$ \\ ${ }^{1}$ Department of Pharmacology, Rutgers Graduate School of Biomedical Science, Piscataway, New Jersey \\ 2 Rutgers Cancer Institute of New Jersey, New Brunswick, New Jersey \\ ${ }^{3}$ Department of Surgery, The First Affiliated Hospital of Harbin Medical University, Harbin, China \\ ${ }^{4}$ G.W. Hooper Research Foundation, University of California, San Francisco, CA \\ ${ }^{5}$ Department of Medicine, Robert Wood Johnson Medical School, New Brunswick, New Jersey \\ ${ }^{6}$ Department of Pathology, Robert Wood Johnson Medical School, New Brunswick, New Jersey \\ Correspondence to: Sharon R. Pine, email: pinesr@cinj.rutgers.edu
}

Keywords: Sox9, Notch1, TGF- $\beta$, lung cancer, EMT

Received: April 1, $2014 \quad$ Accepted: May 12, $2014 \quad$ Published: May 13, 2014

This is an open-access article distributed under the terms of the Creative Commons Attribution License, which permits unrestricted use, distribution, and reproduction in any medium, provided the original author and source are credited.

\section{ABSTRACT}

Sox9 has gained increasing importance both functionally and as a prognostic factor in cancer. We demonstrate a functional role for Sox9 in inducing a mesenchymal phenotype in lung ADC. We show that Sox9 mRNA and protein are overexpressed in lung ADC, particularly those with KRAS mutations. Sox9 expression correlated with the Notch target gene Hes1, and numerous other Notch pathway components. We observed that Sox9 is a potent inducer of lung cancer cell motility and invasion, and a negative regulator of E-cadherin, a key protein that is lost during epithelialmesenchymal transition (EMT). Moreover, we show that Notch1 signaling directly regulates Sox9 expression through a SOX9 promoter binding site, independently of the TGF- $\beta$ pathway, and that Sox9 participates in Notch-1 induced cell motility, cell invasion, and loss of E-cadherin expression. Together, the results identify a new functional role for a Notch1-Sox9 signaling axis in lung ADC that may explain the correlation of Sox9 with tumor progression, higher tumor grade, and poor lung cancer survival. In addition to Notch and TGF- $\beta$, Sox9 also acts downstream of NF$\kappa B$ and $W n t / \beta$-catenin signaling. Thus, Sox9 could potentially act as a hub to mediate cross-talk among key oncogenic pathways in lung ADC. Targeting Sox9 expression or transcriptional activity could potentially reduce resistance to targeted therapy for lung ADC caused by pathway redundancy.

\section{INTRODUCTION}

Sox9 is a member of the high-mobility group-box class DNA-binding protein family of transcription factors and plays a critical role in embryonic development, cell fate determination and lineage commitment. Specifically, $\operatorname{Sox} 9$ orchestrates chondrogenesis, bone formation and testis development [1,2]. Germline SOX9 mutations cause campomelic dysplasia, a disorder characterized by numerous skeletal abnormalities and XY sex reversal [3]. Infants with mutant $S O X 9$ usually die due to respiratory distress shortly after birth [4]. This clinical finding likely reflects the role of Sox9 in the developing lung. During development, $\operatorname{Sox} 9$ is required for branching morphogenesis in the lungs and for controlling alveolar epithelial progenitor cell proliferation $[5,6]$.

Overexpression of Sox 9 is found in more than $50 \%$ of lung adenocarcinomas (ADCs), the most common histological lung cancer subtype, and is associated with a poor lung ADC survival $[7,8]$. Over the past 5 years, it has become increasingly clear that Sox 9 plays a major role across numerous human cancers. Sox 9 overexpression 
acts as an oncogene in several cancer types, including breast, colorectal, pancreatic, and prostate cancer and glioma [9-13], although it appears to act as a tumor suppressor in bladder cancer and melanoma [14,15]. In lung cancer, $\operatorname{Sox} 9$ overexpression was recently shown to increase cell proliferation and xenograft tumor formation [16] [8]. However, the functional role of Sox 9 in lung cancer has not been fully elucidated. Furthermore, the upstream oncogenic molecular pathways regulating $\operatorname{Sox} 9$ overexpression in lung ADC have not been completely delineated.

The Notch signaling pathway regulates cell fate decisions in nearly every developing tissue and organ, and maintains adult tissue homeostasis. In humans, the Notch receptor is activated after binding to one of 5 Delta or Jagged ligands that are expressed on neighboring cells. Ligand binding initiates a series of cleavage events, and the final cleavage is carried out by the $\gamma$-secretase protease complex which frees the intracellular domain portion of Notch (ICD), allowing Notch ICD to translocate to the nucleus. Nuclear Notch ICD complexes with the transcriptional repressor $R B P-J \kappa$, converting it into a transcriptional activator [17]. Notch ICD-induced effects on gene expression are tightly controlled by numerous post-translational modifications and protein co-factors. Several Notch target genes are nearly universally activated across many cell types and developmental processes, such as Hes and Hey, while many other Notch target genes are highly cell-type and context specific [18,19].

Notch 1 is a putative oncogene that is aberrantly over-activated in over one-third of lung ADCs through gain-of-function mutations (10\%) or altered expression of Notch receptors and/or suppressors (30\%) [20]. Notch1 is required for tumor initiation in the $K R A S$-driven lung ADC mouse model [21]. Moreover, overexpression of constitutively activated Notch1 directly participates in lung carcinogenesis; it induces lung adenomas in mice which progress to ADCs in cooperation with Myc overexpression [22]. Aberrant Notch1 signaling contributes to acquired resistance to EGFR inhibitors, the most widely used targeted therapy for NSCLC [23]. Functionally, Notch increases lung cancer stem cell (CSC) self-renewal and promotes epithelial-mesenchymal transition (EMT) [23,24], reviewed in [25], although the downstream mechanisms mediating these effects have not been fully defined. Few studies have identified specific target genes of oncogenic Notch1 in lung ADC, but those validated thus far include Survivin and IGF1R [26,27]. Because of the exquisite specificity of cell-type and context specific effects of Notch signaling, it is necessary to explore Notch target genes in lung cancer in order to elucidate the genes mediating Notch-induced EMT within this disease.

Sox9 is a well-studied downstream effector of the Notch pathway in murine tissues, especially during development [28-34], through $R B P-J_{\kappa}$ binding sites located at positions $+40 \mathrm{bp}$ and $-325 \mathrm{bp}$ relative to the SOX9 transcriptional start site [35]. However, these binding sites are not conserved in humans. Sox 9 expression correlates with Notch signaling in humans [36], but there has been a lack of direct evidence that Notch-induced modulation of $\operatorname{Sox} 9$ expression is evolutionarily conserved in humans or that $\operatorname{Sox} 9$ is a Notch target in lung cancer. Loss of the TGF- $\beta$ adaptor $\beta 2 S P$ induces $T G F-\beta$ signaling, resulting in both Notch activation and $S O X 9$ expression in esophageal ADC [37]; although, the specific role of Notch in regulating $\operatorname{Sox} 9$ expression was not fully delineated. In this study, we show that the Notch1-Sox9 signaling axis is evolutionarily conserved through a novel $R B P-J_{\kappa}$ binding site at $-10 \mathrm{bp}$ relative to the $S O X 9$ promoter and that $\operatorname{Sox} 9$ expression is regulated by Notch1 in lung ADC independent of $T G F-\beta$ signaling. Further, we demonstrate that $\operatorname{Sox} 9$ mediates Notch1-induced cell motility, invasion, morphological changes, and suppression of E-cadherin, all features of a mesenchymal phenotype.

\section{RESULTS}

\section{Sox9 expression is elevated in $K R A S$-mutant lung ADC.}

An analysis of publicly available datasets [38-47] on Oncomine (www.oncomine.com) revealed an upregulation of $\operatorname{Sox} 9$ mRNA in the majority of lung ADC datasets. Out of 10 available datasets comprising a total of 1,021 samples, 8 datasets with 762 samples showed statistically significant upregulation of Sox9 in lung ADC tumor tissue in comparison to normal adjacent tissue (Fig. 1A). We screened a panel of 14 lung ADC cell lines, and observed detectable levels of Sox 9 protein in 10 cell lines. Low Sox 9 expression was found in immortalized bronchial epithelial Beas $2 b$ cells (Supplementary Fig. S1). We further investigated $\operatorname{Sox} 9$ expression at the protein level in 50 human lung ADC surgical samples and paired NATs. Sox 9 protein levels were significantly higher in tumors than in NAT (Fig. 1B). Sox9 protein was predominantly nuclear and overexpressed in $70 \%$ of human ADCs. In contrast, normal adjacent lung tissue was scored negative, though vascular endothelial cells showed weak positive nuclear and cytoplasmic staining (Fig. 1B), and, when present, bronchial epithelial cells showed moderate cytoplasmic staining with focal nuclear staining.

To further investigate $\operatorname{Sox} 9$ overexpression in lung ADC, we queried data with annotated mutational information and analyzed Sox 9 expression within lung cancer genetic subgroups, including EGFR and $K R A S$ mutations. Sox 9 mRNA was significantly higher in lung ADCs with KRAS mutations compared to NAT. EGFR mutant tumors had a trend of higher Sox 9 expression than in NAT, but it was not statistically significant (Fig. 
1C). These data are consistent with the report that $\operatorname{Sox} 9$ overexpression is required for oncogenic Kras-induced pancreatic intraepithelial neoplasia [48]. To investigate if high $\operatorname{Sox} 9$ expression is conserved in a GEMM of lung $\mathrm{ADC}$, we stained lung adenoma and ADC sections from the LSL-K-rasG12D lung ADC mouse model for Sox 9 and observed $\operatorname{Sox} 9$ protein expression to be mostly absent from normal lung and adenoma tissue, but highly expressed in ADC tumors (Fig. 1D). Expression was not uniform in the tumors and was restricted to the more malignant-appearing outgrowths.

\section{Sox9 is a Notch-responsive gene during murine lung carcinogenesis.}

Notch1 was recently shown to be required for the LSL-K-rasG12D lung ADC GEMM [21]. We analyzed if Sox 9 is a downstream effector of Notch1 during lung carcinogenesis. Notch1 overexpression in the mouse lung alveolar epithelium, driven by the Clara cell specific protein (CCSP) promoter, leads to pulmonary adenomas that progress to ADCs when crossed with conditional Myc overexpression [22]. We tested these conditional GEMM of lung ADC to determine if Sox 9 expression is an early event downstream of Notch1 signaling (Fig. 2A). As previously reported, within 14 days of doxycycline induced N1ICD expression, hyperplastic regions were clearly discernable in stained lung sections (Fig. 2B) [22]. These hyperplastic regions progressed to adenomas with papillary histology in doxycycline-fed Notch1 mice. Immunohistochemical staining for Notch1 demonstrated high expression levels in the hyperplastic and adenomatous regions. Similarly, Sox 9 protein was substantially upregulated in the hyperplastic and adenomatous regions (Fig. 2B). Moreover, multifocal ADCs developed in mice conditionally expressing both N1ICD and Myc driven by the CCSP promoter when induced by doxycycline. Notch protein was highly expressed in this model, and Sox 9 displayed a similar pattern (Fig. 2B). To test if enhanced
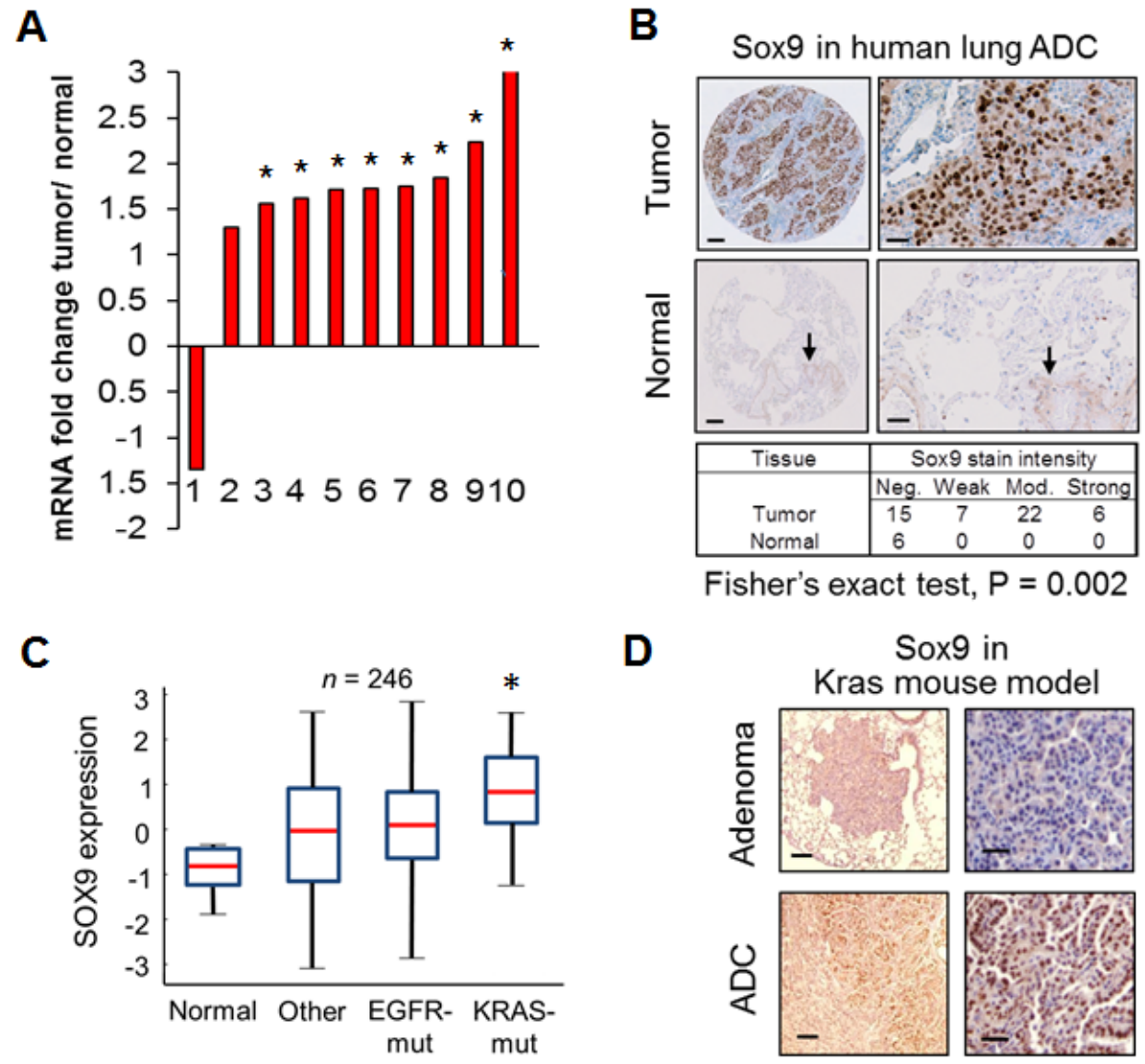

Fisher's exact test, $P=0.002$

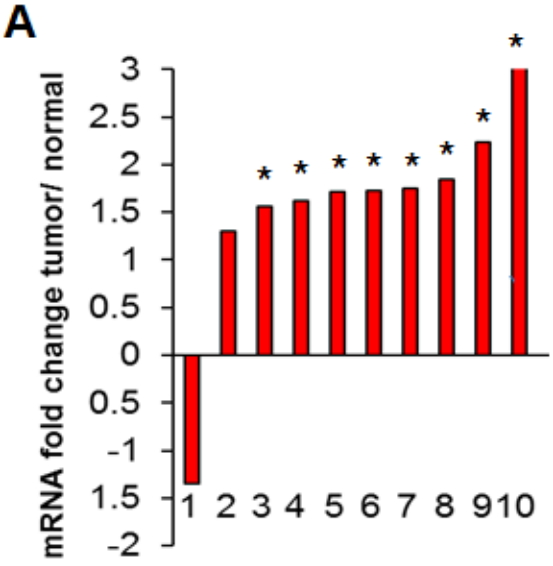

D

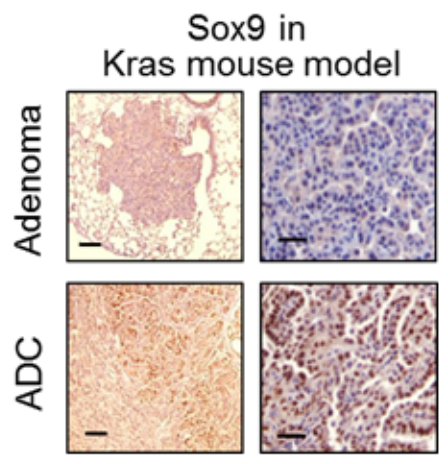

Figure 1: Sox9 expression in lung adenocarcinoma. (A) Fold change in log2 median-centered intensity of mRNA expression levels in lung ADC samples, as compared to normal lung tissue samples, in publicly available datasets. Fold change in tumors is relative to 1 for normal tissues; *, P $<0.05$. (B) Surgical lung ADC samples were immunohistochemically stained for Sox9. Representative staining is shown in human lung ADC and normal adjacent tissue samples. Quantified scores of staining intensity are shown. Arrows indicate light staining in the vascular endothelium. Scale bar for left panel, $100 \mu \mathrm{m}$ and for right panel, $25 \mu \mathrm{m}$. (C) Normalized $S O X 9 \mathrm{mRNA}$ expression levels from human lung ADC samples categorized by genetic subgroups were compared to their respective sets of normal adjacent tissues; *, $\mathrm{P}<0.05$. (D) Representative immunohistochemical staining ( $=4$ mice) of lung tissue sections for Sox 9 is shown from the LSL-KrasG12D lung ADC mouse model. Scale bar for left panel, $200 \mu \mathrm{m}$ and for right panel, $50 \mu \mathrm{m}$. 
$\operatorname{Sox} 9 \operatorname{transcription}$ was responsible for the increased $\operatorname{Sox} 9$ protein levels in these mouse models, we assessed $\operatorname{Sox} 9$ mRNA expression and found an 18-fold increase in lung tissue as early as 7 days after Notch1 induction (Fig. 2C). Levels continued to increase over time through to adenoma formation, and also in the ADC samples from the Notch1-Myc mice (Fig. 2C). These data indicate that Sox 9 is responsive to Notch signaling as an early event during Notch1-induced lung carcinogenesis in vivo.

To determine if $\operatorname{Sox} 9$ expression correlates with Notch signaling in human lung ADC, we performed gene co-expression analyses across several datasets. There was a signficant correlation between Sox 9 and Hes 1 expression, a common Notch-target gene, in 3 of 3 examined studies (Fig. 2D and Supplementary Fig. S2). Both Hes1 and Sox9 positively correlated with the catalytic enzyme that cleaves Notch PSEN1, the Notch ligand JAG1, and positive modulators of Notch signaling, DTX2 and LFNG. Hes 1 and Sox 9 both negatively correlated with MFNG, which inhibits ligand-dependent Notch activation (Fig. 2E and Supplementary Table S1).
A
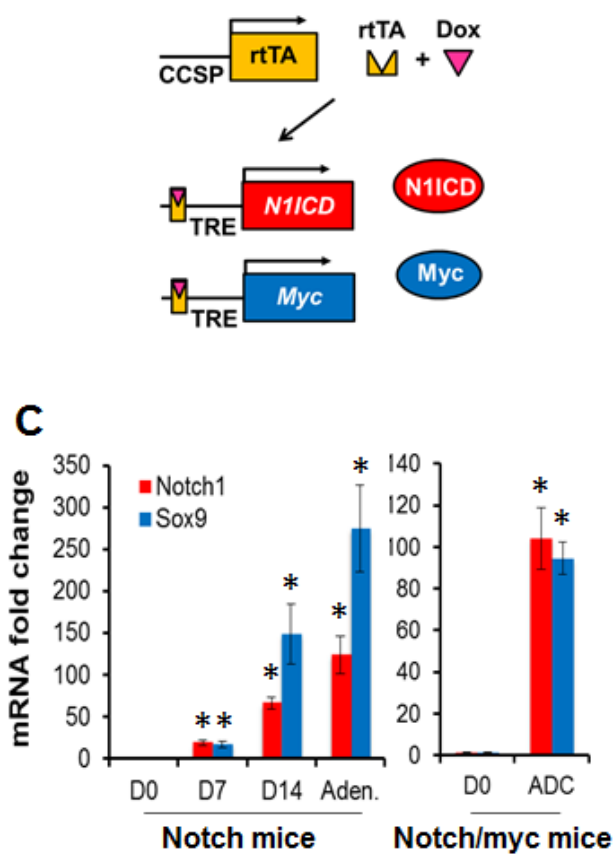

D

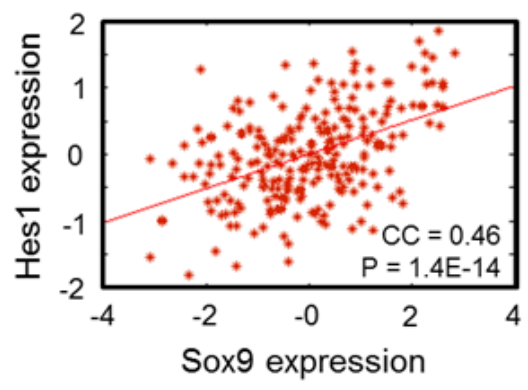

$\mathbf{B}$
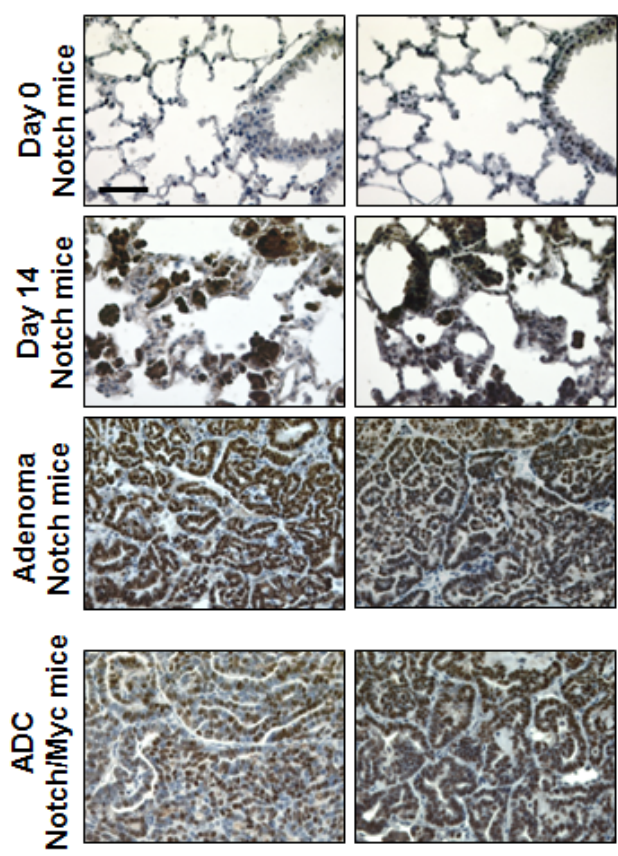

E

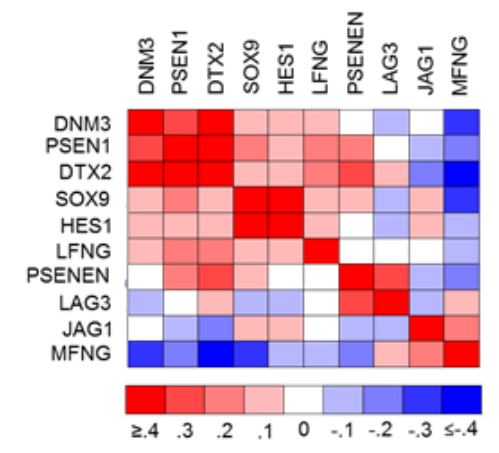

Figure 2: Sox9 is downstream of Notch1 during murine carcinogenesis and correlates with the Notch pathway. (A) Schematic depicting how Myc and Notch1 transgenes were conditionally expressed in lung epithelial cells with doxycycline (DOX) treatment. (B) Lung tissue sections from the Notch1 (Day 0, Day 14 and adenoma) or Notch1/Myc (Adenocarcinoma) lung cancer mouse models were immunohistochemically stained for Sox 9 and Notch1 expression. Scale bar, $50 \mu \mathrm{m}$; all pictures are the same magnification. (C) SOX9 mRNA levels were assayed in a set of mouse lung tissues from the indicated conditions ( $\mathrm{n}=3$ mice each). Mean fold changes with standard deviations, compared to no doxycycline treatment, are shown; *, P $<0.05$. (D) Linear regression of normalized SOX9 and HES1 mRNA levels [41]. (E) Heat map of Pearson correlation coefficients of mRNA gene expression across Sox 9 and genes that modulate the Notch pathway. Raw data and $\mathrm{P}$ values are detailed in Supplementary Table 1. 


\section{Sox9 is responsive to Notch1 signaling in human lung adenocarcinoma.}

Because $\operatorname{Sox} 9$ was a reported target gene of the Notch pathway during murine development and we found a significant correlation between the Notch pathway and Sox 9 expression at the mRNA level across microarray datasets of lung ADC samples, we set out to determine if Sox9 is a key gene downstream of Notch in lung ADC. We treated lung ADC cells with EDTA, known to induce Notch activation by chelating calcium [49]. EDTA-induced Notch activation consistently upregulated expression of Hes 1 at least 5-fold at both the RNA and protein levels (Fig. 3A and Supplementary Fig. S3). We observed dosedependent inhibition of Notch by the gamma-secretase inhibitor (GSI) RO4929097 (Supplementary Fig. S4). The GSI substantially blocked EDTA-induced Hes 1 expression (Fig. 3A, left panel). Similarly, Sox9 expression was significantly increased after EDTA-induced Notch activation in 3 of 4 lung ADC cell lines examined, and Sox9 upregulation was significantly eliminated in the presence of the GSI (Fig. 3A, right panel), suggesting that Sox9 is highly responsive to Notch signaling in lung ADC. The intensities of upregulated Sox 9 and Hes 1 expression induced by Notch signaling were different, as is typical of Notch-target genes $[28,50]$.

We next set out to determine if $\operatorname{Sox} 9$ is downstream of Notch1 or Notch3, the two Notch receptors implicated in lung ADC [20,24,26]. We knocked down Notch1 expression in H1299 cells, which had high basal Sox9 protein levels among the screened cell lines, and Sox 9 mRNA and protein expression were repressed (Fig. 3B, Supplementary Fig. S5A). Similar results were observed in A549 and H1650 cells, but not in H358 cells (Fig. 3B), suggesting that other upstream pathways might also drive $\operatorname{Sox} 9$ expression. Conversely, knockdown of Notch3 failed to decrease Sox 9 expression in any of the 4 cell lines tested. However, in two cell lines, Notch3 silencing increased Sox 9 expression, concomitant with an
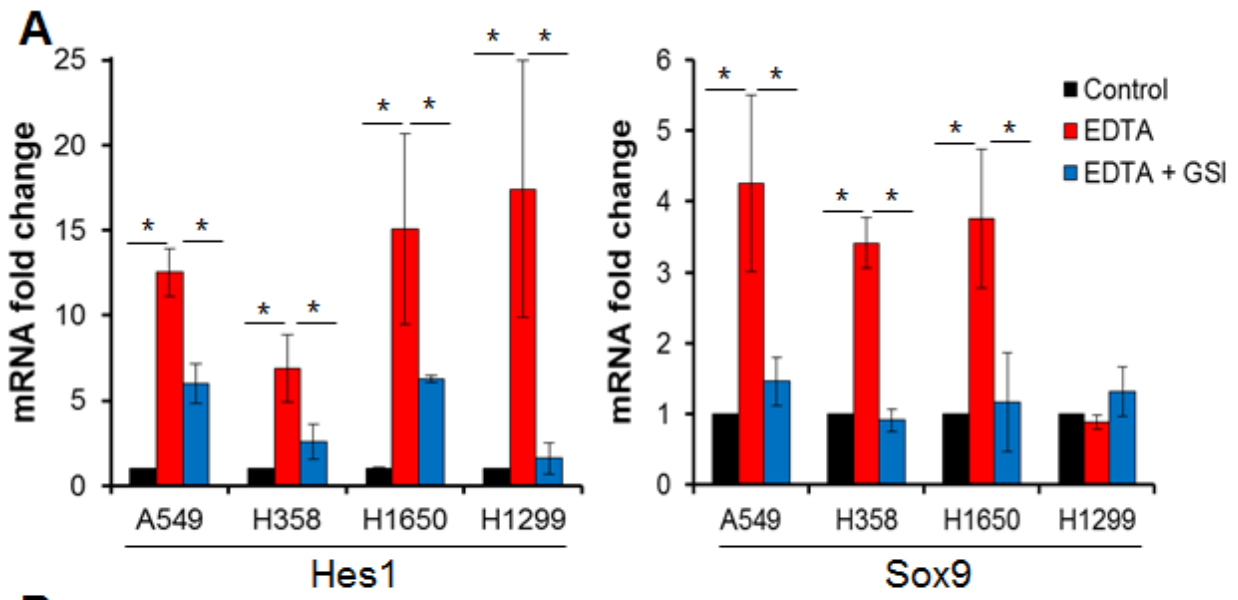

B

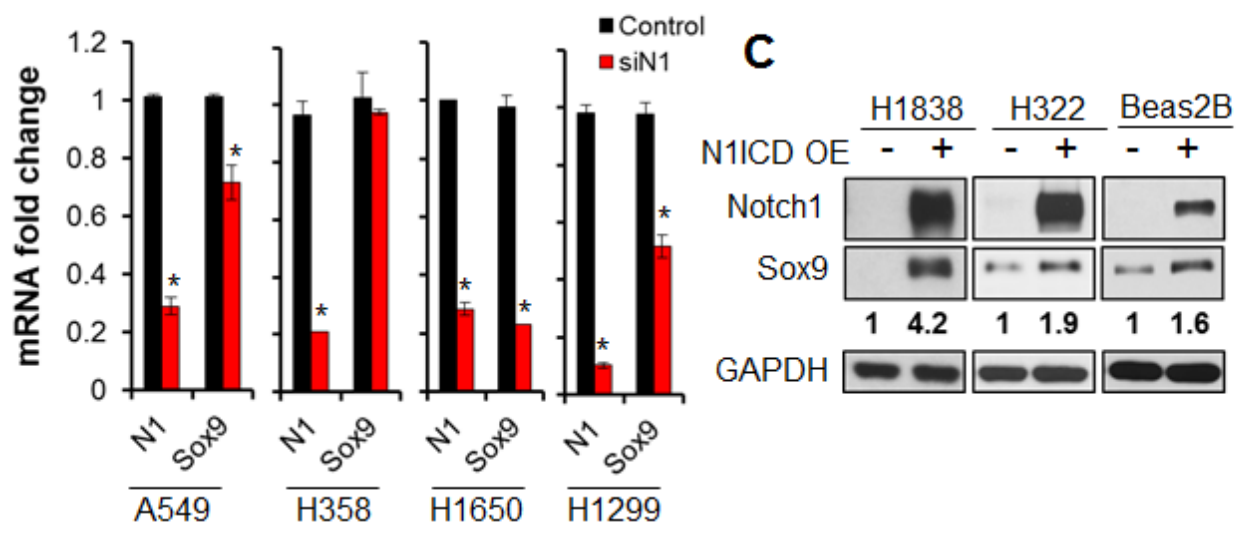

Figure 3: $\operatorname{Sox} 9$ is downstream of Notch signaling in human lung cancer. (A) Mean mRNA levels and standard deviations of HES1 and SOX9 assessed by quantitative RT-PCR are shown in untreated lung ADC cells, after EDTA-induced Notch activation, and after Notch activation was blocked by a gamma secretase inhibitor; ${ }^{*}, \mathrm{P}<0.05$. (B) mean mRNA fold change and standard deviations of Notch1 and Sox 9 are shown in lung adenocarcinoma cells 72 hours after transient transfection with siRNA against Notch1 as compared to transfection with a scrambled siRNA (Control); *, P < 0.05. (C) Expression of Notch1 and Sox9 were analyzed by western blot in lung $\mathrm{ADC}$ and immortalized bronchial epithelial cells 48 hours after transfection with vector or Notch1 intracellular domain. Quantification by densitometry, normalized to GAPDH protein levels, is shown. 
increase in Notch1 mRNA caused by Notch3 knockdown (Supplementary Fig. S5B and C). This was likely due to a compensatory increase in Notch1 secondary to decreased Notch3 signaling, a known Notch1 antagonist [51]. Overexpression of the active form of Notch1 (N1ICD) induced Sox 9 expression in lung ADC cell lines and immortalized bronchial epithelial cells that had low basal Sox9 levels (Fig. 3C). These data confirmed that Notch1 signaling influences Sox 9 expression in human lung ADC.

\section{Notch1 directly regulates Sox 9 gene expression.}

Recently, two $R B P-J \kappa$ binding sites in the murine $S O X 9$ promoter were identified at approximately $-325 \mathrm{bp}$ $(\mathrm{S} 2)$ and +40 bp (S5) relative to the transcriptional start site (Fig. 4A) [35,52]. Alignment of the mouse and human Sox 9 promoters revealed that these mouse $R B P-J_{\kappa}$ binding sites are not conserved in humans (Fig. 4A). We queried -950 to +50 bp relative to the human transcriptional start site using the LASAGNA algorithm [53] and identified two novel $R B P-J \kappa$ binding motifs with potential high affinity located at positions $-81 \mathrm{bp}$ (S3) and -10 bp (S4) (Fig. 4A). To test whether direct binding of NIICD to these RBP-JK binding sites in the human $\operatorname{Sox} 9$ promoter is necessary for induction of $\operatorname{Sox} 9$ expression in human NSCLC, we used a luciferase reporter under the control of a $1 \mathrm{~kb}$-fragment of the $\operatorname{Sox} 9$ promoter, transiently expressed in the Sox 9 low H1838 cells. Activity of the wild-type reporter was induced 4.5-fold, when co-transfected with N1ICD (Fig. $4 C$ ). We mutated the four putative $R B P-J \kappa$ binding sites, as well as one additional site (Site 1) proposed by Song et al. [37] to cooperate with the Smad3 SBE (Smad binding element) upstream of Sox9 in esophageal adenocarcinoma (Fig. 4B). Only mutation of Site 4, that we identified by LASAGNA, abolished activation of the luciferase reporter activity by $N 1 I C D$, showing that this -10 bp site is, indeed, a functional site responsible for the induction of $\operatorname{Sox} 9$ by Notch1 in human lung ADC (Fig. 4C). Consistent with these data, we performed ChIP-QPCR assays on H1838 cells transiently transfected with $N 1 I C D$, using primers designed to amplify Site 4, and found that N1ICD physically associated with the $R B P-J \kappa$ binding site in the human Sox 9 promoter at or near the -10 bp site (Fig. 4D and E). Taken together, these results establish $\operatorname{Sox} 9$ as a direct transcriptional Notch1 target in human lung ADC.

Because Smad3 was recently shown to interact with Notch1 in esophageal adenocarcinoma cells after treatment with $T G F-\beta$, we tested if N1ICD binding to the Sox 9 promoter $R B P-J \kappa$ site was dependent on $T G F-\beta$ signaling in lung ADC. $T G F-\beta$ increased Smad3 phosphorylation (Fig. 4F) and significantly induced $\operatorname{Sox} 9$ reporter luciferase activity in both the wild-type and mutated Site 4 promoters by 2 -fold (Fig. 4G). Combined TGF- $\beta$ treatment with transient overexpression of N1ICD resulted in an additive increase in luciferase activity, compared to either one individually, indicating that Sox9-promoter driven gene expression does not require cooperativity of $N 1 I C D$ and $T G F-\beta$ in lung ADC. Further, $T G F-\beta$ treatment induced an additive increase in the basal luciferase activity even with a mutation at Site 4, confirming that N1ICD does not bind the putative site immediately upstream of the Smad3 binding site in lung ADC. Inhibition of TGF- $\beta$ signaling by SB431542 abolished $T G F-\beta$-induced Smad3 phosphorylation (Fig. 4F) but had no effect on $N 1 I C D$-induced luciferase activity (Fig. 4G). These data confirm that Notch 1 and $T G F-\beta$ induce $\operatorname{Sox} 9$ expression independently in lung ADC.

\section{Sox9 mediates Notch1-induced cell motility and suppression of epithelial-like cellular morphology.}

To determine if Sox9 affects cell motility, we carried out in vitro wound-healing assays with H1299 and A549 cells, which have high Sox9 expression (Supplementary Fig. S1). Knockdown of either Notch1 or $\operatorname{Sox} 9$ significantly reduced migration, as compared to cells transfected with a scrambled siRNA sequence. Overexpression of Sox 9 rescued the reduced cell motility caused by loss of Notch1 signaling, in both H1299 (Fig. 5A and B) and A549 cells (Supplementary Fig. S6A). We then tested if silencing Sox 9 could block Notch-enhanced migration. Transient overexpression of activated Notch1 increased A549 cell motility, though not significantly. However, silencing of $\operatorname{Sox} 9$ expression reversed the increased cell motility caused by activated Notch1, down to similar levels seen with silenced Notch1 (Supplementary Fig. S6B). These data demonstrate that $\operatorname{Sox} 9$ at least partly mediates Notch1-induced cell migration.

H1299 cells are characterized by a mesenchymal gene expression signature and spindle-shaped morphology with few cell-cell contacts. Compared with control cells, H1299 cells with knocked down Notch1 or Sox 9 expression underwent profound morphologic changes, which included a larger, flattened phenotype and tighter, more numerous cell-cell contacts. When Sox9 was overexpressed in cells with knocked down Notch1, the mesenchymal appearance of the cells was rescued, with characteristic spindle-like shape and loss of tight cell-cell contacts (Fig. 5C).

\section{Sox9 mediates Notch1-induced cell invasion and loss of epithelial marker expression.}

Because our data suggested that $\operatorname{Sox} 9$ mediates the adoption of a mesenchymal phenotype induced by Notch1, we analyzed cell invasion, a hallmark of mesenchymal cells. Transient Notch1 or Sox 9 knockdown significantly reduced invasion of H1299 cells through Matrigel-coated Transwell inserts, and transient overexpression of $\operatorname{Sox} 9$ rescued the cells' invasive ability (Fig. 6A and B). 
A

Smad3
Human A GGTGGGGTAGATCCTAGTCCAGACACACACTTGC--GCGCACACACACACACACAC

B

D

\begin{tabular}{|c|c|c|}
\hline & WT & Mut \\
\hline Site1 & GGTGGGGG & GAGTACTG \\
\hline Site2 & TCGCGCG & TGAATCAG \\
\hline Site3 & CCTGGGAC & CTGTATGC \\
\hline Site4 & GCTGGGAG & GTGTATCG \\
\hline Site5 & AGTGGCG & AAGTATG \\
\hline
\end{tabular}

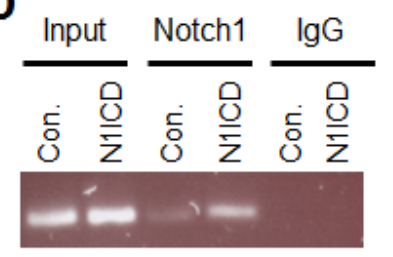

$\mathbf{F}$
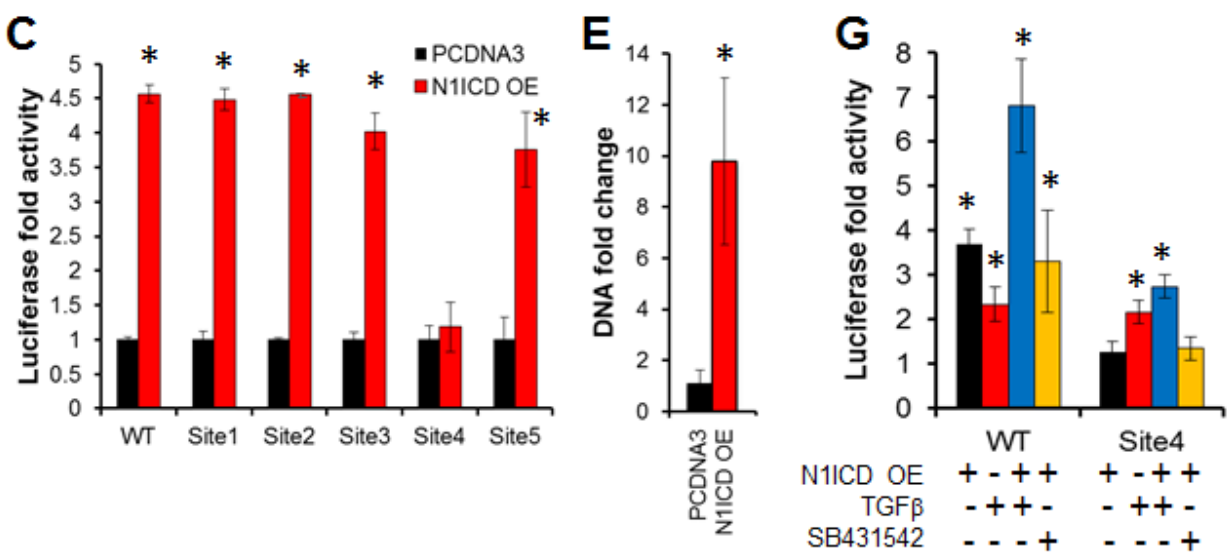

Figure 4: Sox9 is a Notch1 target gene in lung adenocarcinoma. (A) Alignment of the human and mouse $S O X 9$ promoter sequences is shown, with indicated putative $R B P-J \kappa$ binding Sites 1 - 5 and Smad3 binding element, relative to the $S O X 9$ transcriptional tart site (TSS). Sites 1, 2, and 5 were previously reported (See text), and we identified Sites 3 and 4 through LASAGNA, (B) Wild-type and mutated primer sequences used for site-directed mutagenesis of Sites 1 - 5 are shown. (C) Normalized luciferase fold activity (to Renilla luciferase) and standard deviations in cells co-transfected with Notch1 intracellular domain (NIICD OE) and a luciferase reporter driven by a $1 \mathrm{~kb}$ fragment of the wild-type or mutated SOX9 promoter in sites $1-5$, compared to the vector control (PCDNA3); *, P $<0.05$. (D) ChIP was performed using either a Notch1 or IgG control antibody on cells transfected with N1ICD or a control vector (PCDNA3), and the $S O X 9$ promoter was amplified by PCR, using primers that were designed to amplify Site 4. (E) Quantitative PCR was performed after ChIP; *, P $<0.05$. (F) pSmad3 was analyzed by western blot after treatment with vehicle controls, recombinant human $T G F-\beta$ or the $T G F-\beta$ inhibitor, SB431542. (G) normalized luciferase fold activity (to Renilla luciferase) in cells transfected with N1ICD and a luciferase reporter driven by a $1 \mathrm{~kb}$ fragment of the wild-type or mutated $S O X 9$ promoter at Site 4, and treatment with $T G F-\beta$ or SB431542, each compared to its empty vector control, which was set to 1 (Not shown); *, $\mathrm{P}<0.05$. 
The cell-cell adhesion molecule E-cadherin is a major determinant of epithelial features. In line with the morphological changes, E-cadherin expression was substantially increased after knockdown of Notch1 expression in H1299 cells. Overexpression of Sox 9 substantially, though not completely, blocked the upregulation of E-cadherin expression caused by knockdown of Notch1 (Fig. 6C and Supplementary Fig. S6C). Similarly, in A549 cells, repression of Sox 9 upregulated E-cadherin protein expression, even in the presence of activated Notch1 ICD overexpression (Supplementary Fig. S6D). Knockdown of Notch1 significantly reduced expression of $M M P 9$, Slug and Snail, however, overexpression of $\operatorname{Sox} 9$ did not rescue expression of these genes after Notch1 knockdown. Furthermore, modulation of Sox 9 expression did not affect mRNA levels of Vimentin, CEACAM1, Twist, Zeb1 or Zeb2 (Data not shown). To establish the correlation between Sox 9 and E-cadherin expression in vivo, we stained the human lung ADC tumors for E-cadherin. We found a significant inverse correlation between E-cadherin and $\operatorname{Sox} 9$ staining intensities (Fig. 6D and E). Together, these findings suggest that $\operatorname{Sox} 9$ may be a gatekeeper partly mediating Notch's role in EMT by inducing loss of epithelial features, blocking E-cadherin expression, and increasing cell motility and invasion.

\section{DISCUSSION}

$\operatorname{Sox} 9$ is a developmental gene required for lineage commitment in numerous tissue and organs, including the lung. It is well-accepted that genes regulating development also play critical roles in cancer development and progression, and thus it is not surprising that Sox 9 expression is dysregulated in cancer. $\operatorname{Sox} 9$ is overexpressed in several tumor types and associated with poor survival $[8,16,54]$. Upregulation of Sox 9 expression was reported to increase cell proliferation $[9,11,16]$, and induce invasion in pancreatic, prostate, and urothelial cancer $[12,55,56]$. Sox9 cooperates with Slug to induce EMT
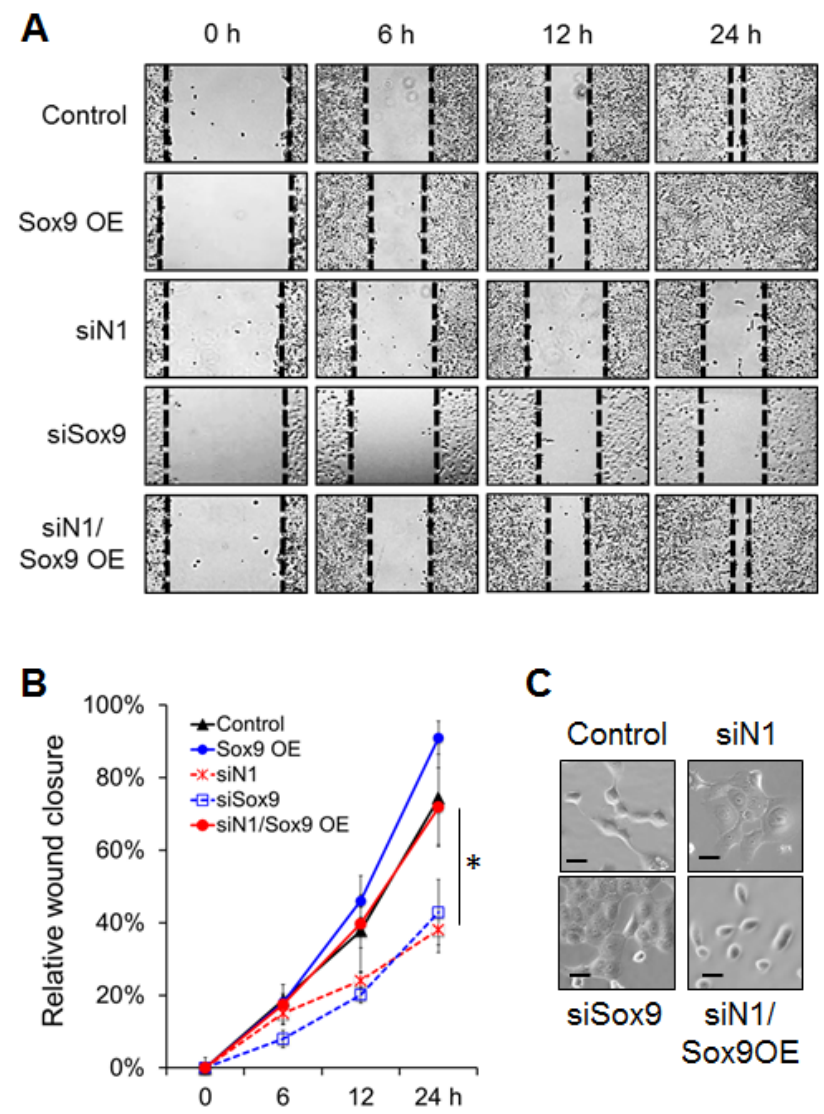

Figure 5: Sox9 mediates Notch1-induced cell migration and morphological changes. (A) Migration ability of lung adenocarcinoma cells was examined with a wound healing assay starting at 48 hours after transient knockdown of Notch1 or Sox9, or overexpression (OE) of Sox9. The control sample was transfected with both a scrambled siRNA sequence and empty vector. Representative images are shown at $0,6,12$ and 24 hours. Black dotted lines indicate the wound edge closure of monolayer cells. (B) Mean migration distance of the wound edge, and standard error of the mean, is shown in all treatment compared to cells transfected with both a scrambled siRNA sequence and empty vector (Control); *, P < 0.05. (C) Representative brightfield images of lung ADC cells 72 hours after knockdown of Notch1 or Sox9, or Sox 9 overexpression, compared to cells transfected with both a scrambled siRNA sequence and empty vector (Control). Scale bar, $10 \mu \mathrm{m}$. 
in mammary stem cells, and tumor progression in breast cancer [10]. These reports in total indicate the importance of examining the pathways inducing $\operatorname{Sox} 9$ dysregulation and to fully delineate the mechanisms through which Sox 9 participates in lung carcinogenesis and tumor progression.

We demonstrate that $\operatorname{Sox} 9$ is overexpressed at the mRNA level across the majority of publicly available datasets and at the protein level in 50 primary lung ADC tumors, consistent with previous reports $[8,16]$. We show that $\operatorname{Sox} 9$ is overexpressed within the lung ADC subgroup that harbors KRAS mutations, and confirm that $\operatorname{Sox} 9$ is overexpressed within the more malignant portions of tumor from the LSL-K-rasG12D lung ADC mouse model [9]. The Notch pathway cooperates with Kras in development of murine pancreatic intraepithelial neoplasia (PanIN) [57] and lung ADC [21]. Furthermore, Sox9 overexpression induces acinar-to-ductal reprogramming and cooperates with Kras during PanIN formation [48].

In $K R A S$-mutant lung ADCs, $\operatorname{Sox} 9$ overexpression may be secondary event associated with tumor progression [9], rather than directly downstream of the Kras pathway. Conversely, in the murine model of Notch1-induced lung cancer, Sox 9 is overexpressed as early as 7 days after induction of Notch1 overexpression in the alveolar epithelium, specifically confined to the alveolar hyperplastic regions, and thus is likely to be directly downstream of Notch. We propose that Sox 9 participates as a primary downstream Notch effector early in Notch1-induced carcinogenesis, but as a secondary event during KRAS-mutant lung carcinogenesis, and both Kras and Notch contribute significantly to lung tumor formation. Further studies are needed to determine if, 1) Sox 9 overexpression is required for tumor formation in the Kras and Notch1 lung cancer mouse models, 2) if Sox9 acts downstream of Kras or Notch in the Kras lung cancer mouse model, and 3) if $\operatorname{Sox} 9$ alone can drive the development of premalignant or malignant lesions.

Aberrantly activated Notch signaling is associated
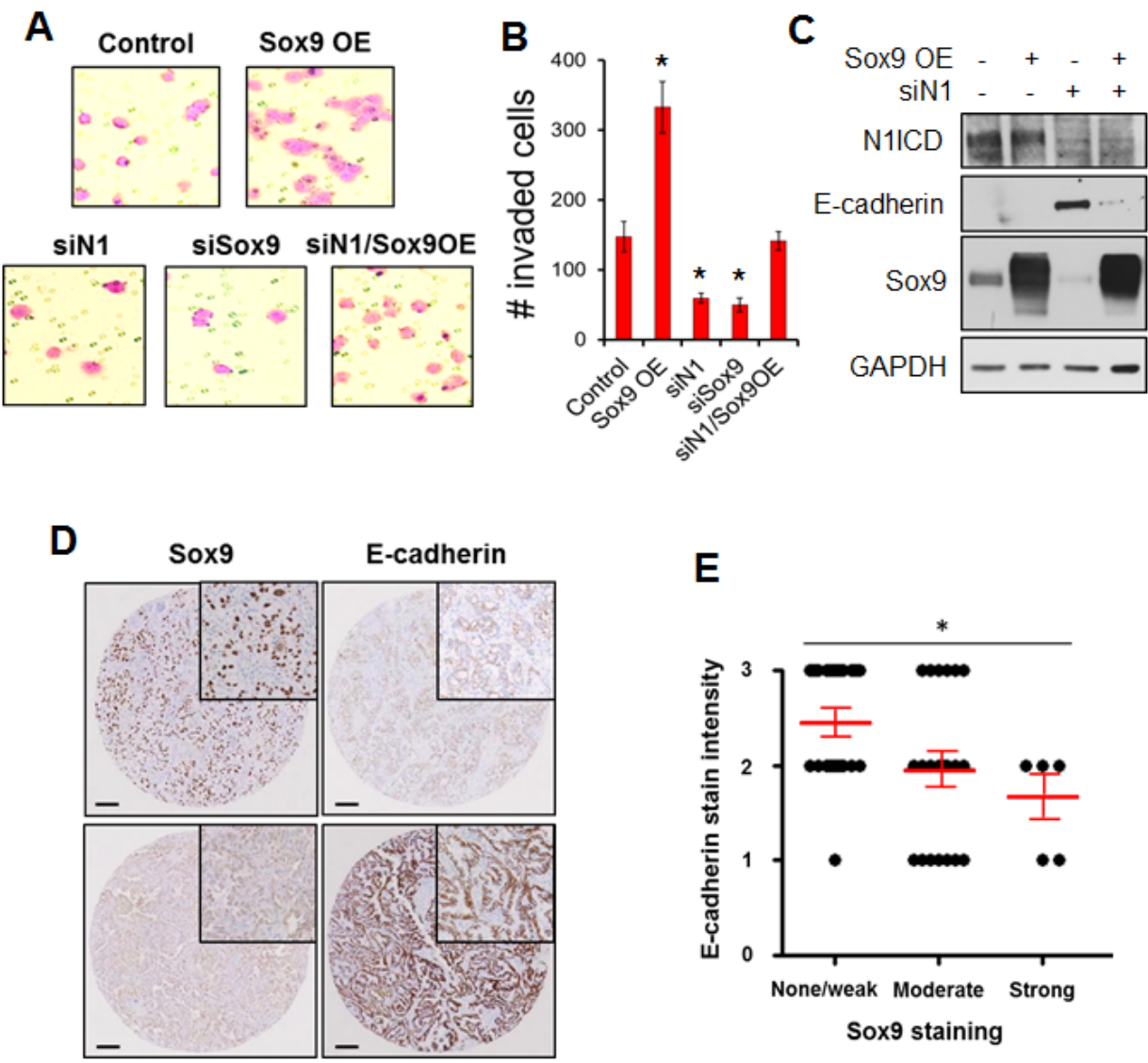

Figure 6; $\operatorname{Sox} 9$ mediates Notch1-induced cell invasion and expression of E-cadherin. (A) invasion assays were performed on H1299 lung ADC cells 48 hours after transient knockdown of Notch1 or Sox9, or overexpression (OE) of Sox9 compared to cells transfected with both a scrambled siRNA sequence and empty vector (Control). Representative images show crystal violet-stained invaded cells. (B) Total number of invaded cells from experiments in A were quantified and compared to the control samples; *, P < 0.05. (C) Intracellular Notch1 (NIICD), E-cadherin and Sox9 were analyzed by western blot 72 hours after transient knockdown of Notch1 or overexpression of Sox9, or transfection with a scrambled siRNA sequence and empty vector, in H1299 cells. (D) Lung ADC tumors were immunohistochemically stained for Sox 9 and E-cadherin. Representative staining is shown in human lung adenocarcinoma samples with high (upper panel) or low (lower panel) Sox9 staining. Scale bar, $100 \mu \mathrm{m}$. (E) Quantified Sox9 and E-cadherin immunohistochemical stain intensity scores were graphed; *, $\mathrm{P}<0.05$. 
with poor survival, CSCs, EMT, and chemoresistance in lung cancer [23,24,58,59]; however, very little is known about the downstream genes mediating the effects of Notch in lung ADC [26,27]. We show that Sox 9 is not only a direct target of Notch1 in lung ADC but also functionally mediates Notch1-induced cell motility, invasion, and mesenchymal-like characteristics. While we observed that Sox 9 overexpression decreased E-cadherin, the mode by which this happens is unclear. A search of $5 \mathrm{~kb}$ upstream of the E-cadherin transcription start site revealed no $\operatorname{Sox} 9$ binding sites. Future studies are needed to investigate the mechanisms by which $\operatorname{Sox} 9$ regulates E-cadherin expression. Work is also needed to examine if Sox 9 mediates Notch-induced chemo- and radio-resistance, as well as CSC self-renewal.

This study has important clinical implications since Notch signaling is aberrantly over-activated not only in $40 \%$ of lung ADCs but across numerous tumor types [17]. Gamma secretase inhibitors that inhibit Notch activation, and monoclonal antibodies are in clinical trials, but they are largely ineffective due to dose-limiting toxicities or development of resistance [60-62]. Clearly, novel methods to target the tumorigenic effects of Notch while minimizing toxicities are necessary. The results of this study could be an impetus for investigations for inhibiting Sox 9 transcriptional activity or expression.

\section{MATERIALS AND METHODS}

\section{Cell culture and drug treatments}

Human bronchial epithelial Beas2b cells were a kind gift of Dr. John Langenfeld, A549, H1299, H358, H1650, H322, H441, H1975, H838, H1838, H23, and H1755 cell lines were obtained from the American Type Culture Collection (ATCC), and Sk-Lu-1, H2030, and HCC-44 cell lines were a gift from Bristol Myers Squibb (Princeton, NJ). Cells were cultured in media as recommended by ATCC and maintained at $37^{\circ}$ with $5 \% \mathrm{CO}_{2}$ and ambient $\mathrm{O}_{2}$. For EDTA-induced Notch activation, cells were exposed to $1 \mathrm{mM}$ EDTA or culture media for $30 \mathrm{~min}$, then placed back in culture media for 1 hour. For inhibition of Notch activation, cells were treated with $1 \mu \mathrm{M}$ RO4929097 or DMSO for 48 hours. Human recombinant $T G F-\beta$ (PeproTech) was used at a concentration of $10 \mathrm{ng} /$ $\mathrm{ml}$ for 48 hours. $T G F-\beta$ inhibitor $\mathrm{S} 431542$ (Sigma) was used at a concentration of $10 \mu \mathrm{M}$ for 48 hours.

\section{Human patient samples}

Formalin-fixed paraffin embedded tissue specimens were obtained through the Tissue Retrieval Service, Rutgers Cancer Institute of New Jersey, from patients who underwent surgery at Robert Wood Johnson University
Hospital. This study was approved by the Institutional Review Board of Rutgers Robert Wood Johnson Medical School.

\section{Genetically engineered mouse models (GEMM)}

Animal experimentation was conducted with the approval of the Institutional Animal Care and Use Committee of the University of California, San Francisco, CA. Mice expressing the doxycycline-responsive reverse tetracycline transactivator (rtTA) driven by the rat Clara cell secretory protein (CCSP) promoter, mice with a tetracycline-responsive promoter element controlling expression of human MYC, and mice with a tetracyclineresponsive promoter element controlling expression of human N1ICD, have been previously described [22]. Transgenic mice were fed with a supplemental diet containing doxycycline $(200 \mathrm{mg} / \mathrm{kg})$. Tissue sections were obtained and RNA samples were extracted as previously reported [22].

\section{Immunohistochemical analysis and scoring}

Surgical specimens were collected by the Tissue Retrieval Services, and a tissue array comprising 50 lung $\mathrm{ADC}$ and 6 normal adjacent tissue (NAT) samples were prepared as $1 \mathrm{~mm}$ diameter cores in duplicate on two slides, totaling 4 cores per tissue, by the Histopathology and Imaging Shared Resource, at Rutgers Cancer Institute of New Jersey. Tumor/tissue quality was monitored under the guidance of a clinical pathologist. Immunohistochemical staining was done by permeabilizing with $0.1 \%$ Triton $\mathrm{X}-100$ in PBS for 10 minutes, quenching endogenous peroxides with $3 \%$ hydrogen peroxide for 10 minutes, followed by blocking, as well as primary and secondary antibody incubation. Immunoreactivity was visualized with 3,3'-diaminobenzidine (DAB, Sigma). The primary antibodies used were: Sox9 (1:50, HPA001758, Sigma), E-cadherin (pre-diluted, 760-4440, Ventana), Notch1 (1:100, EP1238Y, Epitomics).

Samples for which at least $25 \%$ of the tumor cells stained positive were considered positive. Staining intensity was scored as 0 , negative; 1 , weak; 2 , moderate; and 3, strong. Scoring was performed in a blinded manner by two clinical pathologists and discordant results were discussed until a consensus was reached.

\section{Western blot analyses}

Monolayer cells were washed and lysed with freshly prepared lysis buffer. Total cell lysates $(20 \mu \mathrm{g})$ were assayed by western blot using standard procedures. Cleaved Notch1 and E-cadherin were visualized using high-intensity ECL. All others were visualized with 
standard ECL. Protein levels in all experiments were normalized to either GAPDH or $\alpha$-tubulin. The following antibodies were used: Sox9 (AB5535, Millipore), cleaved Notch1 (Val1744, 4147S, Cell Signaling), fulllength Notch1 (C20, 6014, Santa Cruz), Hes1 (25392, Santa Cruz), E-cadherin (21791, Santa Cruz), GAPDH (MAB374, Millipore) and $\alpha$-tubulin (T9026, Sigma).

\section{Real-time quantitative RT-PCR (Q-PCR)}

Total RNA was isolated using TRIzol (Invitrogen) and further purified using Qiashredder columns then by the RNeasy Mini kit (both from Qiagen Ltd., Germany) following standard protocols. RNA quantity and quality was assessed using a Nanodrop spectrophotometer. Reverse transcription was carried out using the Qiagen QuantiTect Reverse Transcription Kit in accordance with the manufacturer's instructions, followed by Q-PCR on a Stratagene Mx3005P machine using SYBR Green according to standard procedures. Primers were synthesized by IDT and results were analyzed using Microsoft Excel. Each assay was done at least in biological and PCR triplicate. Specificity of PCR amplification was assessed regularly using a melting-curve analysis. $\beta$-actin was used as the internal standard for normalization.

\section{siRNA and plasmid transfections}

For siRNA transfection, a mixture of 20 pM siRNA (3 different siRNA sequences pooled) and $1 \mu \mathrm{L}$ RNAiMax was diluted in Optimem. Experiments were performed 48or 72-hours post-transfection. siRNA oligos were obtained from Santa Cruz (siNotch1- sc-36095; siNotch2- sc40137; siNotch3- sc-37135; siNotch4- sc-40135; siSox9sc-36533; scr- sc-37007; FITC-A- sc-36869). Plasmid transfections were performed using Fugene transfection reagent. $N 1 I C D$ cloned into pcDNA3.0 (Invitrogen) was a kind gift of Dr. Lucio Miele. The SOX9-pCMV-Tag2V expression vector was a kind gift of Dr. I-Shou Chang. In all experiments, scrambled siRNA sequence, or vectoronly plasmids, or both, were used as controls.

\section{Chromatin immunoprecipitation assay}

The chromatin immunoprecipitation (ChIP) assay was done according to the manufacturer's protocol (Upstate Biotechnology) in triplicate and on 2 separate occasions. In short, chromatin was cross-linked to DNA by adding formaldehyde to tissue culture dishes to a final concentration of $0.75 \%$. Formaldehyde was neutralized and cells were scraped, washed, and resuspended in lysis buffer. Samples were sonicated to 200-500 bp fragments, diluted in ChIP dilution buffer, pre-cleared with salmon sperm DNA-protein A agarose slurry, centrifuged, and the supernatant was collected. Samples were incubated with immunoprecipitating Notch1 or control IgG antibody overnight at $4^{\circ} \mathrm{C}$ with rotation. Immune complexes were collected with salmon sperm DNA-protein A agarose slurry, then washed with low-salt immune complex buffer, high-salt immune complex buffer, $\mathrm{LiCl}$ immune complex buffer, and twice with TE buffer. Input DNA was removed for later normalization, then remaining samples were eluted, cross-links were reversed by incubation at $65^{\circ} \mathrm{C}$ overnight, and DNA was purified using the Qiagen Gel Extraction kit. Quantitative PCR was performed as outlined above, using the following primer to amplify the Sox9 Site 4 (Fig. 4A) promoter region: forward primer: 5'- GGACTGCTGTGCTG-TGATTG-3', reverse primer: 5'- AGTTTCGAGCTCCGCTTTCG -3'. Samples were subsequently run on a $1.5 \%$ gel.

\section{Site directed mutagenesis and luciferase assay}

The pGL2 firefly luciferase reporter plasmid under the control of the $\operatorname{Sox} 9$ promoter was a kind gift of Dr. William L. Farrar. Mutations were induced using sitedirected-mutagenesis primers in conjunction with the Agilent QuikChange II Site Directed Mutagenesis kit, according to the manufacturer's protocol. Cells were co-transfected with one of these plasmids and either the $N 1 I C D$ or empty vector in triplicate. After $48 \mathrm{hrs}$, cells were harvested for determination of luciferase activity by a luminometer. A Renilla luciferase plasmid was used for normalization. Mutagenesis primers are listed in Supplementary Methods.

\section{Wound healing motility assay}

Cells were plated such that they would be $95-100 \%$ confluent at the start of the assay. Cells were transfected 48 hours prior to creating a single scratch wound in triplicate wells. The wound closure experiment was performed in $2 \%$ fetal bovine serum to reduce potential differences in cell proliferation. Images were obtained at various timepoints after wounding.

\section{Matrigel invasion assay}

H1299 cells were transfected 48 hours prior to trypsinization and plated onto Matrigel invasion chambers (BD Biosciences) without serum. The chemoattractant in the lower chamber was $10 \%$ fetal bovine serum. The invasion assay was conducted for a minimum of 24 hours to reduce confounding due to potential differences in cell proliferation. Uninvaded cells were removed, and invaded cells were fixed with 4\% PFA for 10 minutes, and stained with $0.05 \%$ crystal violet. Invaded cells were manually scored. 


\section{Statistical analysis}

All reported values represent the mean and standard deviation (SD) of at least three independent experiments, unless otherwise noted. All experiments were performed in biological triplicate and repeated at least once. Student's t-tests were used for statistical comparisons. Correlation between Sox9 and E-cadherin staining was done by a Kruskal-Wallis test. Correlation coefficients between mRNA levels in microarray datasets were obtained by Pearson correlation. A P value $\leq .05$ was considered statistically significant. All tests were done using Microsoft Excel or Stata version 12.

\section{ACKNOWLEDGEMENTS}

We thank Drs. Lucio Miele, I-Shou Chang, and William L. Farrar for their kind gifts of plasmids used in this study. We thank Dr. Karin Cohen-Solal for her advice on the TGF- $\beta$ experiments and for the SB431542 TGF- $\beta$ inhibitor. We are thankful to Sohrab Amiri for technical assistance. We thank Julie Friedman from the Tissue Retrieval Shared Resource, and David Foran from the Histopathology and Imaging Shared Resource, Rutgers Cancer Institute of New Jersey. We are thankful to Marina Chekmareva for her oversight during TMA building and IHC optimization. We thank D. John Langenfeld for the Beas $2 b$ cell line. We are thankful to Dr. Shridar Ganesan for advice on the ChIP assays. We are appreciative to Drs. Joseph Bertino and Hatem Sabaawy for continued advice and for critical review of this manuscript.

\section{Grant Support}

This work was supported by a career development grant from the NCI, National Institutes of Health K22CA140719 to S.R.P.

\section{REFERENCES}

1. Akiyama H, Lefebvre V. Unraveling the transcriptional regulatory machinery in chondrogenesis. J Bone Miner Metab. 2011; 294: 390-395.

2. Lee YH, Saint-Jeannet JP. Sox9 function in craniofacial development and disease. Genesis. 2011; 494: 200-208.

3. Schafer AJ, Foster JW, Kwok C, Weller PA, Guioli S, Goodfellow PN. Campomelic dysplasia with XY sex reversal: diverse phenotypes resulting from mutations in a single gene. Ann N Y Acad Sci. 1996; 785: 137-149.

4. Schafer AJ, Dominguez-Steglich MA, Guioli S, Kwok C, Weller PA, Stevanovic M, Weissenbach J, Mansour S, Young ID, Goodfellow PN, . The role of SOX9 in autosomal sex reversal and campomelic dysplasia. Philos Trans R Soc Lond B Biol Sci. 1995; 3501333: 271-277.
5. Rockich BE, Hrycaj SM, Shih HP, Nagy MS, Ferguson MA, Kopp JL, Sander M, Wellik DM, Spence JR. Sox9 plays multiple roles in the lung epithelium during branching morphogenesis. Proc Natl Acad Sci U S A. 2013; 11047 : E4456-E4464.

6. Turcatel G, Rubin N, Menke DB, Martin G, Shi W, Warburton D. Lung mesenchymal expression of Sox9 plays a critical role in tracheal development. BMC Biol. 2013; 11: 117.

7. Lu Y, Okubo T, Rawlins E, Hogan BL. Epithelial progenitor cells of the embryonic lung and the role of microRNAs in their proliferation. Proc Am Thorac Soc. 2008; 53: 300-304.

8. Zhou CH, Ye LP, Ye SX, Li Y, Zhang XY, Xu XY, Gong LY. Clinical significance of SOX9 in human non-small cell lung cancer progression and overall patient survival. J Exp Clin Cancer Res. 2012; 31: 18.

9. Matheu A, Collado M, Wise C, Manterola L, Cekaite L, Tye AJ, Canamero M, Bujanda L, Schedl A, Cheah KS, Skotheim RI, Lothe RA, Lopez de MA et al. Oncogenicity of the developmental transcription factor Sox9. Cancer Res. 2012; 725: 1301-1315.

10. Guo W, Keckesova Z, Donaher JL, Shibue T, Tischler V, Reinhardt F, Itzkovitz S, Noske A, Zurrer-Hardi U, Bell G, Tam WL, Mani SA, van OA et al. Slug and Sox9 cooperatively determine the mammary stem cell state. Cell. 2012; 1485: 1015-1028.

11. Wang L, He S, Yuan J, Mao X, Cao Y, Zong J, Tu Y, Zhang Y. Oncogenic role of SOX9 expression in human malignant glioma. Med Oncol. 2012; 295: 3484-3490.

12. Sun L, Mathews LA, Cabarcas SM, Zhang X, Yang A, Zhang Y, Young MR, Klarmann KD, Keller JR, Farrar WL. Epigenetic Regulation of SOX9 by the NF-kappaB Signaling Pathway in Pancreatic Cancer Stem Cells. Stem Cells. 2013; 318: 1454-1466.

13. Wang G, Lunardi A, Zhang J, Chen Z, Ala U, Webster KA, Tay Y, Gonzalez-Billalabeitia E, Egia A, Shaffer DR, Carver B, Liu XS, Taulli R et al. Zbtb7a suppresses prostate cancer through repression of a Sox9-dependent pathway for cellular senescence bypass and tumor invasion. Nat Genet. 2013; 457: 739-746.

14. Passeron T, Valencia JC, Namiki T, Vieira WD, Passeron $\mathrm{H}$, Miyamura Y, Hearing VJ. Upregulation of SOX9 inhibits the growth of human and mouse melanomas and restores their sensitivity to retinoic acid. J Clin Invest. 2009; 1194: 954-963.

15. Aleman A, Adrien L, Lopez-Serra L, Cordon-Cardo C, Esteller M, Belbin TJ, Sanchez-Carbayo M. Identification of DNA hypermethylation of SOX9 in association with bladder cancer progression using $\mathrm{CpG}$ microarrays. Br J Cancer. 2008; 982: 466-473.

16. Jiang SS, Fang WT, Hou YH, Huang SF, Yen BL, Chang JL, Li SM, Liu HP, Liu YL, Huang CT, Li YW, Jang $\mathrm{TH}$, Chan $\mathrm{SH}$ et al. Upregulation of SOX9 in lung adenocarcinoma and its involvement in the regulation of 
cell growth and tumorigenicity. Clin Cancer Res. 2010; 1617: 4363-4373.

17. Capaccione KM, Pine SR. The Notch signaling pathway as a mediator of tumor survival. Carcinogenesis. 2013; 347: 1420-1430.

18. Sakano D, Kato A, Parikh N, McKnight K, Terry D, Stefanovic B, Kato Y. BCL6 canalizes Notch-dependent transcription, excluding Mastermind-like1 from selected target genes during left-right patterning. Dev Cell. 2010; 183: 450-462.

19. Bray SJ. Notch signalling: a simple pathway becomes complex. Nat Rev Mol Cell Biol. 2006; 79: 678-689.

20. Westhoff B, Colaluca IN, D'Ario G, Donzelli M, Tosoni D, Volorio S, Pelosi G, Spaggiari L, Mazzarol G, Viale G, Pece S, Di Fiore PP. Alterations of the Notch pathway in lung cancer. Proc Natl Acad Sci U S A. 2009; 10652: 22293-22298

21. Licciulli S, Avila JL, Hanlon L, Troutman S, Cesaroni M, Kota S, Keith B, Simon MC, Pure E, Radtke F, Capobianco AJ, Kissil JL. Notch1 Is Required for Kras-Induced Lung Adenocarcinoma and Controls Tumor Cell Survival via p53. Cancer Res. 2013.

22. Allen TD, Rodriguez EM, Jones KD, Bishop JM. Activated Notch1 induces lung adenomas in mice and cooperates with Myc in the generation of lung adenocarcinoma. Cancer Res. 2011; 7118: 6010-6018.

23. Xie M, He CS, Wei SH, Zhang L. Notch-1 contributes to epidermal growth factor receptor tyrosine kinase inhibitor acquired resistance in non-small cell lung cancer in vitro and in vivo. Eur J Cancer. 2013.

24. Hassan KA, Wang L, Korkaya H, Chen G, Maillard I, Beer DG, Kalemkerian GP, Wicha MS. Notch pathway activity identifies cells with cancer stem cell-like properties and correlates with worse survival in lung adenocarcinoma. Clin Cancer Res. 2013; 198: 1972-1980.

25. Espinoza I, Miele L. Deadly crosstalk: Notch signaling at the intersection of EMT and cancer stem cells. Cancer Lett. 2013; 3411: 41-45

26. Eliasz S, Liang S, Chen Y, De Marco MA, Machek O, Skucha S, Miele L, Bocchetta M. Notch-1 stimulates survival of lung adenocarcinoma cells during hypoxia by activating the IGF-1R pathway. Oncogene. 2010; 2917: 2488-2498.

27. Chen Y, Li D, Liu H, Xu H, Zheng H, Qian F, Li W, Zhao C, Wang Z, Wang X. Notch-1 signaling facilitates survivin expression in human non-small cell lung cancer cells. Cancer Biol Ther. 2011; 111: 14-21.

28. Shih HP, Kopp JL, Sandhu M, Dubois CL, Seymour PA, Grapin-Botton A, Sander M. A Notch-dependent molecular circuitry initiates pancreatic endocrine and ductal cell differentiation. Development. 2012; 13914: 2488-2499.

29. Nakanishi K, Chan YS, Ito K. Notch signaling is required for the chondrogenic specification of mouse mesencephalic neural crest cells. Mech Dev. 2007; 1243: 190-203.
30. Martini S, Bernoth K, Main H, Ortega GD, Lendahl U, Just U, Schwanbeck R. A critical role for Sox 9 in notch-induced astrogliogenesis and stem cell maintenance. Stem Cells. 2013; 314: 741-751.

31. Muto A, Iida A, Satoh S, Watanabe S. The group E Sox genes Sox 8 and Sox 9 are regulated by Notch signaling and are required for Muller glial cell development in mouse retina. Exp Eye Res. 2009; 894: 549-558.

32. Taylor MK, Yeager K, Morrison SJ. Physiological Notch signaling promotes gliogenesis in the developing peripheral and central nervous systems. Development. 2007; 13413: 2435-2447.

33. Fujimaki R, Toyama Y, Hozumi N, Tezuka K. Involvement of Notch signaling in initiation of prechondrogenic condensation and nodule formation in limb bud micromass cultures. J Bone Miner Metab. 2006; 243: 191-198.

34. Mead TJ, Yutzey KE. Notch pathway regulation of chondrocyte differentiation and proliferation during appendicular and axial skeleton development. Proc Natl Acad Sci U S A. 2009; 10634: 14420-14425.

35. Meier-Stiegen F, Schwanbeck R, Bernoth K, Martini S, Hieronymus T, Ruau D, Zenke M, Just U. Activated Notch1 target genes during embryonic cell differentiation depend on the cellular context and include lineage determinants and inhibitors. PLoS One. 2010; 57: e11481.

36. Candy PA, Phillips MR, Redfern AD, Colley SM, Davidson JA, Stuart LM, Wood BA, Zeps N, Leedman PJ. Notchinduced transcription factors are predictive of survival and 5-fluorouracil response in colorectal cancer patients. Br J Cancer. 2013; 1094: 1023-1030.

37. Song S, Maru DM, Ajani JA, Chan CH, Honjo S, Lin HK, Correa A, Hofstetter WL, Davila M, Stroehlein J, Mishra L. Loss of TGF-beta adaptor beta2SP activates notch signaling and SOX9 expression in esophageal adenocarcinoma. Cancer Res. 2013; 737: 2159-2169.

38. Stearman RS, Dwyer-Nield L, Zerbe L, Blaine SA, Chan Z, Bunn PA, Jr., Johnson GL, Hirsch FR, Merrick DT, Franklin WA, Baron AE, Keith RL, Nemenoff RA et al. Analysis of orthologous gene expression between human pulmonary adenocarcinoma and a carcinogen-induced murine model. Am J Pathol. 2005; 1676: 1763-1775.

39. Bhattacharjee A, Richards WG, Staunton J, Li C, Monti S, Vasa P, Ladd C, Beheshti J, Bueno R, Gillette M, Loda M, Weber G, Mark EJ et al. Classification of human lung carcinomas by mRNA expression profiling reveals distinct adenocarcinoma subclasses. Proc Natl Acad Sci U S A. 2001; 9824: 13790-13795.

40. Wei TY, Juan CC, Hisa JY, Su LJ, Lee YC, Chou HY, Chen JM, Wu YC, Chiu SC, Hsu CP, Liu KL, Yu CT. Protein arginine methyltransferase 5 is a potential oncoprotein that upregulates G1 cyclins/cyclin-dependent kinases and the phosphoinositide 3-kinase/AKT signaling cascade. Cancer Sci. 2012; 1039: 1640-1650.

41. Okayama H, Kohno T, Ishii Y, Shimada Y, Shiraishi K, 
Iwakawa R, Furuta K, Tsuta K, Shibata T, Yamamoto S, Watanabe S, Sakamoto H, Kumamoto K et al. Identification of genes upregulated in ALK-positive and EGFR/KRAS/ ALK-negative lung adenocarcinomas. Cancer Res. 2012; 721: 100-111.

42. Beer DG, Kardia SL, Huang CC, Giordano TJ, Levin AM, Misek DE, Lin L, Chen G, Gharib TG, Thomas DG, Lizyness ML, Kuick R, Hayasaka S et al. Geneexpression profiles predict survival of patients with lung adenocarcinoma. Nat Med. 2002; 88: 816-824.

43. Garber ME, Troyanskaya OG, Schluens K, Petersen S, Thaesler Z, Pacyna-Gengelbach M, van de Rijn M, Rosen GD, Perou CM, Whyte RI, Altman RB, Brown PO, Botstein $\mathrm{D}$ et al. Diversity of gene expression in adenocarcinoma of the lung. Proc Natl Acad Sci U S A. 2001; 9824: 1378413789.

44. Su LJ, Chang CW, Wu YC, Chen KC, Lin CJ, Liang SC, Lin $\mathrm{CH}$, Whang-Peng J, Hsu SL, Chen $\mathrm{CH}$, Huang CY. Selection of DDX5 as a novel internal control for Q-RTPCR from microarray data using a block bootstrap resampling scheme. BMC Genomics. 2007; 8: 140.

45. Landi MT, Consonni D, Rotunno M, Bergen AW, Goldstein AM, Lubin JH, Goldin L, Alavanja M, Morgan G, Subar AF, Linnoila I, Previdi F, Corno M et al. Environment And Genetics in Lung cancer Etiology (EAGLE) study: an integrative population-based case-control study of lung cancer. BMC Public Health. 2008; 8: 203.

46. Selamat SA, Chung BS, Girard L, Zhang W, Zhang Y, Campan M, Siegmund KD, Koss MN, Hagen JA, Lam WL, Lam S, Gazdar AF, Laird-Offringa IA. Genome-scale analysis of DNA methylation in lung adenocarcinoma and integration with mRNA expression. Genome Res. 2012; 227: 1197-1211.

47. Hou J, Aerts J, den HB, van IW, den BM, Riegman P, van der Leest C, van der Spek P, Foekens JA, Hoogsteden HC, Grosveld F, Philipsen S. Gene expression-based classification of non-small cell lung carcinomas and survival prediction. PLoS One. 2010; 54: e10312.

48. Kopp JL, von FG, Mayes E, Liu FF, Dubois CL, Morris JP, Pan FC, Akiyama H, Wright CV, Jensen K, Hebrok M, Sander M. Identification of Sox9-dependent acinar-to-ductal reprogramming as the principal mechanism for initiation of pancreatic ductal adenocarcinoma. Cancer Cell. 2012; 226: 737-750.

49. Rand MD, Grimm LM, Artavanis-Tsakonas S, Patriub V, Blacklow SC, Sklar J, Aster JC. Calcium depletion dissociates and activates heterodimeric notch receptors. Mol Cell Biol. 2000; 205: 1825-1835.

50. Van dW, I, De SG, De SM, Vandekerckhove B, Leclercq G, Plum J, Taghon T. An early decrease in Notch activation is required for human TCR-alphabeta lineage differentiation at the expense of TCR-gammadelta T cells. Blood. 2009; 11313: 2988-2998.

51. Beatus P, Lundkvist J, Oberg C, Lendahl U. The notch 3 intracellular domain represses notch 1-mediated activation through Hairy/Enhancer of split (HES) promoters. Development. 1999; 12617: 3925-3935.

52. Haller R, Schwanbeck R, Martini S, Bernoth K, Kramer J, Just U, Rohwedel J. Notch1 signaling regulates chondrogenic lineage determination through Sox9 activation. Cell Death Differ. 2012; 193: 461-469.

53. Lee C, Huang CH. LASAGNA-Search 2.0: integrated transcription factor binding site search and visualization in a browser. Bioinformatics. 2014.

54. Wang H, He L, Ma F, Regan MM, Balk SP, Richardson AL, Yuan X. SOX9 regulates low density lipoprotein receptorrelated protein 6 (LRP6) and T-cell factor 4 (TCF4) expression and $\mathrm{Wnt} /$ beta-catenin activation in breast cancer. J Biol Chem. 2013; 2889: 6478-6487.

55. Cai C, Wang H, He HH, Chen S, He L, Ma F, Mucci L, Wang Q, Fiore C, Sowalsky AG, Loda M, Liu XS, Brown $\mathrm{M}$ et al. ERG induces androgen receptor-mediated regulation of SOX9 in prostate cancer. J Clin Invest. 2013; 1233: 1109-1122.

56. Ling S, Chang X, Schultz L, Lee TK, Chaux A, Marchionni L, Netto GJ, Sidransky D, Berman DM. An EGFR-ERKSOX9 signaling cascade links urothelial development and regeneration to cancer. Cancer Res. 2011; 7111: 3812-3821.

57. De La OJ, Emerson LL, Goodman JL, Froebe SC, Illum $\mathrm{BE}$, Curtis AB, Murtaugh LC. Notch and Kras reprogram pancreatic acinar cells to ductal intraepithelial neoplasia. Proc Natl Acad Sci U S A. 2008; 10548: 18907-18912.

58. Liu YP, Yang CJ, Huang MS, Yeh CT, Wu AT, Lee YC, Lai TC, Lee CH, Hsiao YW, Lu J, Shen CN, Lu PJ, Hsiao M. Cisplatin selects for multidrug-resistant CD133+ cells in lung adenocarcinoma by activating Notch signaling. Cancer Res. 2013; 731: 406-416.

59. Sullivan JP, Spinola M, Dodge M, Raso MG, Behrens C, Gao B, Schuster K, Shao C, Larsen JE, Sullivan LA, Honorio S, Xie Y, Scaglioni PP et al. Aldehyde dehydrogenase activity selects for lung adenocarcinoma stem cells dependent on notch signaling. Cancer Res. 2010; 7023: 9937-9948.

60. Wong GT, Manfra D, Poulet FM, Zhang Q, Josien H, Bara T, Engstrom L, Pinzon-Ortiz M, Fine JS, Lee HJ, Zhang L, Higgins GA, Parker EM. Chronic treatment with the gamma-secretase inhibitor LY-411,575 inhibits betaamyloid peptide production and alters lymphopoiesis and intestinal cell differentiation. J Biol Chem. 2004; 27913: 12876-12882.

61. van Es JH, van Gijn ME, Riccio O, van den Born M, Vooijs M, Begthel H, Cozijnsen M, Robine S, Winton DJ, Radtke F, Clevers H. Notch/gamma-secretase inhibition turns proliferative cells in intestinal crypts and adenomas into goblet cells. Nature. 2005; 4357044: 959-963.

62. O’Neil J, Grim J, Strack P, Rao S, Tibbitts D, Winter C, Hardwick J, Welcker M, Meijerink JP, Pieters R, Draetta G, Sears R, Clurman BE et al. FBW7 mutations in leukemic cells mediate $\mathrm{NOTCH}$ pathway activation and resistance to 
gamma-secretase inhibitors. J Exp Med. 2007; 2048: 1813 -

1824. 